\title{
Producción de miel e infestación con Varroa destructor de abejas africanizadas (Apis mellifera) con alto y bajo comportamiento higiénico
}

\section{Honey production and Varroa destructor infestation of Africanized honey bee (Apis mellifera) colonies with high and low hygienic behavior}

\author{
Carlos Aurelio Medina-Floresa, Ernesto Guzmán-Novoab, Carlos Fernando Aréchiga \\ Floresa, Héctor Gutiérrez Bañuelosa, Jairo Iván Aguilera Sotoa
}

\begin{abstract}
RESUMEN
El objetivo del estudio fue comparar la producción de miel y los niveles de Varroa destructor entre colonias de abejas africanizadas (AA) (Apis mellifera) con alto y bajo comportamiento higiénico (CH) en el altiplano semiárido de México. Se midió el nivel de $\mathrm{CH}$ a 57 colonias por congelamiento de la cría con nitrógeno líquido ( $\mathrm{N}_{2}$ ). Las colonias se clasificaron en dos grupos: alto $\mathrm{CH}(>95 \%)$ y bajo $\mathrm{CH}$ ( $<50 \%$ de remoción de la cría muerta por congelamiento en $48 \mathrm{~h}$ ). La producción de miel se evaluó durante el otoño y la primavera y el nivel de infestación por Varroa en abejas adultas se determinó antes y durante las cosechas de miel. En primavera, las colonias con CH alto produjeron significativamente más miel que las de $\mathrm{CH}$ bajo $(21.4 \pm 4.7$ vs $13.4 \pm 5.0 \mathrm{~kg} ; \mathrm{P}<0.01)$. No hubo diferencias entre los dos grupos de colonias para los niveles de Varroa $(\mathrm{P}>\mathbf{0 . 0 5})$. Estos resultados sugieren que aparentemente el comportamiento higiénico no tiene un efecto mayor en la resistencia de las AA al crecimiento poblacional del ácaro. También sugieren que el comportamiento higiénico alto podría contribuir a incrementar la producción de miel en épocas del año con flujo reducido de néctar.
\end{abstract}

PALABRAS CLAVE: Abejas melíferas, Comportamiento higiénico, Varroosis, Tolerancia, Cosecha de miel.

\begin{abstract}
The aim of this study was to compare the honey yields and levels of Varroa destructor between colonies of Africanized honey bees (AHB) (Apis mellifera) showing high and low hygienic behavior (HB) in Mexico's semi-arid high plateau. The degree of $\mathrm{HB}$ of 57 colonies was measured using the liquid nitrogen $\left(\mathrm{N}_{2}\right)$ brood-freezing technique. The colonies were categorized into two groups: high HB ( $>95 \%$ ) and low HB ( $<50 \%$ removal of freeze-killed brood at 48 h). Honey production was evaluated in fall and spring and the level of Varroa on adult bees was determined before and during the honey harvests. The colonies with high HB produced significantly more honey than the colonies with low HB only during the spring crop $(21.4 \pm 4.7$ vs $13.4 \pm 5.0 \mathrm{~kg} ; \mathrm{P}<0.01)$. There were no significant differences between the two groups of colonies for levels of infestation by $V$. destructor $(P>0.05)$. These results suggest that apparently HB does not have a major role in restraining the growth of Varroa populations in AHB. They also suggest that high levels of HB could contribute to increase honey production in AHB colonies during times of the year with limited nectar flow.
\end{abstract}

KEY WORDS: Honey bee, Hygienic behavior, Varroosis, Tolerance, Honey harvest.

\section{INTRODUCCIÓN}

El comportamiento higiénico $(\mathrm{CH})$ de las abejas melíferas (Apis mellifera) es la habilidad de

\section{INTRODUCTION}

The hygienic behavior (HB) of honey bees (Apis mellifera) is the ability of some workers to

Recibido el 21 de agosto de 2013. Aceptado el 7 de enero de 2014

a Universidad Autónoma de Zacatecas, Unidad Académica de Medicina Veterinaria y Zootecnia, Carretera Panamericana Zacatecas Fresnillo Km 31.5, El Cordovel, Enrique Estrada, Zacatecas, México. carlosmedina1@hotmail.com. Correspondencia al primer autor.

b School of Environmental Sciences, University of Guelph, Guelph, ON N1G 2W1, Canada. 
algunas abejas obreras, de detectar, desopercular y remover cría enferma, muerta o parasitada del interior de las celdas de un panal. Este mecanismo, interrumpe el ciclo de algunas enfermedades y limita sus posibilidades de dispersión(1-4).

La expresión del $\mathrm{CH}$ en una colonia de abejas depende de factores como la proporción y edad de las abejas que realizan tareas higiénicas(5-7), la entrada de néctar y polen colectados por las obreras(8-11) y la fortaleza de la colonia(5). Pero el factor más importante en la expresión de este comportamiento, es su componente genético. Numerosos estudios han demostrado que los efectos genéticos sobre este comportamiento influyen más que los ambientales(12-16). Los valores de heredabilidad del $\mathrm{CH}$ que se han publicado han sido variables, pero lo suficientemente altos ( $>0.5$ ) como para establecer que esta característica puede ser usada como criterio de selección en un programa de mejoramiento genético(17-20).

La identificación de colonias que expresan $\mathrm{CH}$ se basa en provocar enfermedad o muerte de las crías operculadas y evaluar el tiempo que las abejas tardan en removerlas. Esto se ha realizado infectando a la cría con esporas de P. larvae(1), insertando un alfiler a través del opérculo de celdas de cría(21) y congelando cría operculada(22). Utilizando estas técnicas, se ha encontrado una baja frecuencia (10 a $20 \%$ ) de colonias comerciales con alto $\mathrm{CH}$ (que remueven $>95 \%$ de cría congelada en $48 \mathrm{~h}$ ) en poblaciones de abejas europeas $(A E)(23,24)$.

El CH es considerado un mecanismo importante de resistencia y tolerancia a enfermedades de la cría, ya que se ha observado que colonias altamente higiénicas presentan menos problemas relacionados con las enfermedades de la cría como la loque americana (Paenibacillus larvae) $(1,10,25)$ y cría calcárea (Ascosphaera apis)(26-28). Aunado a lo anterior, existen evidencias con resultados muy variables en diferentes partes del mundo respecto a la detect, uncap, and remove diseased, dead, or parasitized brood inside comb cells. This mechanism interrupts the cycle of some diseases and limits their ability to spread(1-4).

The expression of HB in a honey bee colony is affected by factors such as the proportion and age of the bees performing hygienic tasks(5-7), the entry of nectar and pollen collected by workers(8-11) and the strength of the colony(5). But the most important factor influencing the expression of this behavior is a genetic component. Numerous studies have shown that genetic effects influence this behavior more than environmental effects(12-16). The published heritability values for HB are variable, but high enough $(>0.5)$ to establish that this trait can be used as selection criteria in breeding programs(17-20).

The identification of colonies expressing HB is done by inducing disease and death in capped brood, and by evaluating the time it takes for the bees to remove the brood. This has been done by infecting brood with spores of $\mathrm{P}$. larvae(1), inserting a pin through brood cappings(21) and freezing capped brood cells(22). Using these techniques, a low frequency (10 to $20 \%$ ) of commercial colonies expressing high HB (which remove $>95 \%$ of freeze-killed brood in $48 \mathrm{~h}$ ) has been found in populations of European honey bees (EHB) $(23,24)$.

$\mathrm{HB}$ is considered an important mechanism of resistance and tolerance to brood diseases of honey bees, since it has been observed that highly hygienic colonies have fewer instances of brood diseases such as American foulbrood (Paenibacillus larvae) $(1,10,25)$ and chalk brood (Ascosphaera apis)(26-28). Additionally, evidence about the importance of $\mathrm{HB}$ on the control of varroosis (Varroa destructor) in different parts of the world shows very variable results(29-32).

It has been reported that Africanized honey bees (AHB) from South America have lower V. destructor infestation levels than $\mathrm{EHB}^{(33)}$ and it has been speculated that the tolerance of 
importancia del $\mathrm{CH}$ sobre el control de la varroosis (Varroa destructor)(29-32).

Se ha reportado que en AA de Sudamérica, los niveles de infestación del ácaro V. destructor son menores que en $\mathrm{AE}^{(33)}$ y se ha especulado que la tolerancia de las AA hacia el ácaro pudiera ser en parte atribuible a su alto $\mathrm{CH}^{(34)}$. Sin embargo, es necesario realizar estudios que revelen el impacto relativo del $\mathrm{CH}$ sobre la tolerancia a Varroa en AA de México.

Por otro lado, la alta expresión del $\mathrm{CH}$ en una colonia, teóricamente pudiera contribuir a la obtención de una mayor producción de miel como consecuencia de una menor frecuencia de enfermedades de la cría. Sin embargo, aun cuando existen múltiples evidencias de la importancia del $\mathrm{CH}$ sobre el control de enfermedades bacterianas y micóticas de la cría, la relación de este comportamiento con la producción de miel aún no es clara, ya que existen pocos trabajos con resultados variables y que se han realizado con $\mathrm{AE}(24,31,35)$.

No existen trabajos que muestren la influencia del $\mathrm{CH}$ sobre la producción de miel y sobre el grado de infestación de $\mathrm{V}$. destructor en colonias de AA. Además, para la implementación de programas de mejoramiento genético, es importante conocer la proporción de colonias altamente higiénicas en poblaciones de AA de distintas regiones, lo cual presumiblemente podría contribuir a incrementar su resistencia a enfermedades y su producción de miel.

El objetivo de este estudio fue determinar la frecuencia de colonias de AA que expresan alto y bajo $\mathrm{CH}$, y si existen diferencias significativas entre estos dos grupos de colonias para los niveles de infestación de Varroa, y para la producción de miel en el altiplano semiárido de México.

\section{MATERIALES Y MÉTODOS}

\section{Ubicación}

El presente trabajo se realizó en laboratorios y colonias pertenecientes a la Unidad Académica
AHB to the mite may be partly attributable to their high expression of $\mathrm{HB}(34)$. However, studies are needed to reveal the relative impact that HB has on Varroa tolerance in AHB of Mexico.

In addition to the above, a high expression level of HB in a colony, could theoretically contribute to more honey production because of a lower frequency of brood diseases. However, even when there are multiple evidences about the importance of HB on the control of fungal and bacterial brood diseases, the relationship of this behavior with honey production is not yet clear, since few studies, showing variable results, have been conducted, and have been done with $\operatorname{EHB}(24,31,35)$.

There are no studies that show the influence of $\mathrm{HB}$ on honey production and on the degree of infestation by $\mathrm{V}$. destructor in AHB colonies. Moreover, it is important to know the proportion of highly hygienic colonies in AHB populations from different regions, to implement breeding programs, which, presumably could contribute to increase their disease resistance and honey production.

The objectives of this study were to determine the frequency of AHB colonies that express high and low $\mathrm{HB}$, and if there are significant differences between these two groups of colonies for levels of Varroa infestation and honey yields at the semiarid high plateau of Mexico.

\section{MATERIALS AND METHODS}

\section{Location}

This study was carried out in laboratories and hives of the Veterinary Medicine Academic Unit at the Autonomous University of Zacatecas. The experimental apiary was installed in the municipality of Jalpa, Zacatecas, Mexico, $21^{\circ}$ $38^{\prime} \mathrm{N}, 100^{\circ} 51^{\prime} \mathrm{W}$, at $1,380 \mathrm{~m}$ asl. This area has low forest deciduous vegetation and a semiwarm, semi-dry climate. The average annual temperature in J alpa is $21.2^{\circ} \mathrm{C}$ and the average annual rainfall is $700 \mathrm{~mm}^{(36)}$. 
de Medicina Veterinaria y Zootecnia de la Universidad Autónoma de Zacatecas. El apiario experimental fue instalado en el municipio de Jalpa, Zacatecas, México, ubicado a $21^{\circ} 38^{\prime} \mathrm{N}$ y $100^{\circ} 51^{\prime} \mathrm{O}$, a $1,380 \mathrm{msnm}$. El área de estudio presenta una vegetación de tipo selva baja caducifolia y un clima semiseco semicálido. La temperatura media anual es de $21.2{ }^{\circ} \mathrm{C}$ y una precipitación media anual de $700 \mathrm{~mm}(36)$.

Evaluación del comportamiento higiénico $(\mathrm{CH})$

Se evaluó el nivel de $\mathrm{CH}$ a 57 colonias de abejas alojadas en colmenas tipo Jumbo. Inicialmente y con la finalidad de establecer la relación entre el tamaño poblacional de las colonias con la expresión del $\mathrm{CH}$, al momento de realizar las pruebas (dos meses previo a la cosecha de otoño), a cada colonia le fue registrado el número de panales cubiertos con abejas y con cría.

El método utilizado para medir el grado de $\mathrm{CH}$ en las colonias fue el descrito por Spivak y Reuter(10), el cual consiste en congelar con nitrógeno líquido $\left(\mathrm{N}_{2}\right)$ una sección de panal conteniendo cría operculada. A cada colonia se le realizaron dos pruebas entre las 10 y $13 \mathrm{~h}$, y hubo un lapso de siete días entre las dos pruebas.

En cada colonia, se seleccionó un panal de cría operculada con pupas de 3 a 4 días(37), ya que esta etapa es la más adecuada para la evaluación del $\mathrm{CH}^{(38)}$. El panal se identificó con el mismo número de la colonia y posteriormente se insertó un cilindro metálico de $8 \mathrm{~cm}$ de diámetro x $10 \mathrm{~cm}$ de altura, sin tapa en ambos extremos, que abarcó aproximadamente 200 celdas operculadas. Colocado el cilindro en el área seleccionada se agregaron $300 \mathrm{ml}$ de $\mathrm{N}_{2}$ (a -195 으) para congelar y matar las pupas. Posteriormente, el cilindro se retiró del panal y se registró el número de celdas congeladas. Finalmente, los panales se regresaron a las colonias de origen. Cuarenta y ocho (48) horas después de la congelación, los panales se
Evaluation of hygienic behavior (HB)

The HB of 57 honeybee colonies housed in jumbo-size hives was evaluated. Initially, and to establish the relationship between the population size of the colonies with the expression of $\mathrm{HB}$ during testing times (two months before the autumn harvest), the number of combs covered with bees and brood was recorded in each colony.

The degree of HB in the colonies was measured following the method by Spivak and Reuter(10), which involves freezing a section of comb containing capped brood with liquid nitrogen $\left(\mathrm{N}_{2}\right)$. Each colony was tested twice during mornings, between 10 and $13 \mathrm{~h}$, and with a $7 \mathrm{~d}$ period between tests.

In each colony, a brood comb containing 3 to 4-d old capped pupae(37) was selected because this is the most appropriate stage to evaluate $\mathrm{HB}$ (38). The comb was identified with the number of the colony and then a metal cylinder of $8 \mathrm{~cm}$ (diameter) $\times 10 \mathrm{~cm}$ (height) open at both ends, was inserted on an area of the comb containing about 200 capped brood cells. Three hundred (300) $\mathrm{ml}$ of $\mathrm{N}_{2}$ (at $-195{ }^{\circ} \mathrm{C}$ ) were poured through the cylinder to freeze and kill the pupae. Subsequently, the cylinder was removed from the comb and the number of frozen cells was recorded. Finally, each comb was returned to its colony of origin. Forty eight (48) hours after freezing, the combs were removed again from their colonies to record the number of freeze-killed pupae that were removed by the bees.

The percentage of HB was estimated by dividing the number of pupae that were removed, by the total number of cells that were initially frozen, and the result was multiplied by 100 . Colonies that in the two tests uncapped and removed $95 \%$ or more of the frozen brood were classified as of high $\mathrm{HB}$, while those that removed $50 \%$ or less of the frozen brood were classified as of low $\mathrm{HB}^{(22)}$. Hence, two groups were formed from the results of these evaluations, one integrated with 18 colonies 
retiraron nuevamente de las colonias para registrar el número de pupas que fueron removidas por las abejas del área congelada.

El porcentaje de $\mathrm{CH}$ se estimó mediante el conteo de las celdas que se removieron entre el total de las celdas que se congelaron inicialmente, y el resultado se multiplicó por 100. Las colonias que en las dos pruebas realizadas desopercularon y removieron el $95 \%$ o más de la cría congelada se clasificaron como de $\mathrm{CH}$ alto, mientras que aquéllas que removieron $50 \%$ o menos de la cría congelada fueron clasificadas como de $\mathrm{CH}$ bajo(22). Por ello, a partir de los resultados obtenidos en estas evaluaciones, se formaron dos grupos; uno de ellos integrado con 18 colonias que presentaron un $\mathrm{CH}$ alto y otro con 11 colonias que mostraron un $\mathrm{CH}$ bajo.

Las reinas de cada una de las colonias seleccionadas fueron marcadas con tinta indeleble en el tórax para su identificación. Además, se realizó un análisis morfométrico a las abejas(39), con el propósito de confirmar la africanización de las colonias.

Evaluación de la producción de miel en las colonias con alto y bajo $\mathrm{CH}$

Posteriormente, con el propósito de identificar una posible asociación entre el $\mathrm{CH}$ y la producción de miel, se registró el número de panales de alza con miel colectados de cada colonia durante las cosechas de otoño y primavera. El total de miel cosechada $(\mathrm{kg})$ de todas las colonias se dividió entre el número de panales colectados al momento de las cosechas, para así obtener un promedio de miel por panal. Este peso promedio se multiplicó por el número de panales cosechados de cada colonia, con la finalidad de estimar el rendimiento individual de las mismas(40).

Evaluación del nivel de infestación de V. destructor

Se determinó el nivel de infestación del ácaro V. destructor en abejas adultas en cada una de showing high $\mathrm{HB}$ and another with 11 colonies showing low HB.

The queens of each of the selected colonies were marked with indelible ink on the thorax for identification. Further, with the purpose of confirming africanization of the colonies, morphometric analysis of bees(39) was performed.

Evaluation of honey production of colonies with high and low HB

To identify a possible association between $\mathrm{HB}$ and honey yield, the number of combs with honey collected from supers of each colony during the autumn and spring blossoms was recorded. The total amount of honey harvested $(\mathrm{kg})$ from all colonies was divided by the total number of combs collected and an average weight of honey per comb was obtained. This average weight was then multiplied by the number of combs harvested for each colony to estimate the individual yields of the colonies (40).

Assessment of V. destructor infestation levels The level of $V$. destructor infestation of each colony was determined on adult bees for the two colony groups (high and low HB) $60 \mathrm{~d}$ before honey harvests and during them, as per de Jong et al(41). This technique involves collecting a sample of approximately 300 adult bees in a vial containing $75 \%$ ethanol; mites are detached from the bees through mechanical agitation and the total number of both mites and bees are recorded. The infestation rate was determined by dividing the mite count by the number of bees and then, multiplying the resulting figure by 100 .

\section{Statistical analysis}

In order to normalize the data on percentages for HB and for Varroa infestation levels, they were arcsine square-root transformed. The data analysis was performed using SAS statistical software (42). To compare the two groups of colonies for number of combs with brood and 
las colonias de los dos grupos (alto y bajo $\mathrm{CH}$ ) 60 días antes de las cosechas y durante éstas, mediante la metodología descrita por de Jong et al(41). Esta técnica consiste en colectar una muestra de aproximadamente 300 abejas adultas en un recipiente con etanol al $75 \%$, para posteriormente mediante agitación mecánica desprender los ácaros adheridos a las abejas. El porcentaje de infestación por el ácaro se determinó mediante el conteo total de ácaros, divididos entre el número de abejas que fueron analizadas y el resultado se multiplicó por 100.

\section{Análisis estadístico}

Con la finalidad de normalizar los datos porcentuales de los valores del $\mathrm{CH}$ y de los niveles de infestación por Varroa de las colonias, estos fueron transformados con la función arcoseno de la raíz cuadrada. El análisis de los datos se realizó utilizando el programa estadístico SAS(42). Para comparar los dos grupos de colonias en cuanto al número de panales con cría y con abejas (población), en cuanto a la producción de miel, y en cuanto a los niveles de varroosis, se utilizó una prueba " $t$ " de Student. Además, se utilizó la prueba de correlación de Pearson para determinar la relación entre el número de panales con cría y con abejas sobre la expresión del $\mathrm{CH}$, así como para determinar la relación de los datos del $\mathrm{CH}$ entre la primera y la segunda evaluación de las colonias.

\section{RESULTADOS}

Los resultados del análisis morfométrico mostraron que todas las colonias experimentales eran africanizadas y que después de realizar dos pruebas de $\mathrm{CH}$ a 57 colonias, se encontró una correlación positiva y significativa en el nivel de $\mathrm{CH}$ registrado entre la primera y la segunda evaluación ( $r=0.62, n=57, P=0.0001)$, lo cual indica que las colonias que remueven un alto porcentaje de la cría congelada en la primera prueba, lo realizan de una manera similar en la segunda. El $31.5 \%$ de las colonias bees (population), for honey production, and for varroosis levels, a Student " $t$ " test was used.

In addition to the above, the Pearson correlation test was used to determine the relationship between the number of combs covered with brood and bees and the expression of $\mathrm{HB}$, and to determine the relationship between the data of the first and the second HB tests.

\section{RESULTS}

The results of morphometric analysis showed that all of the experimental colonies were Africanized. After performing two tests of $\mathrm{HB}$ to 57 colonies, a significant positive correlation in the level of HB recorded between the first and second test was found $(r=0.62, n=57$, $\mathrm{P}=0.0001$ ), indicating that the colonies that remove a high percentage of freeze-killed brood during the first test, perform similarly in the second test. Of the colonies tested $31.5 \%$ (18 out of 57) expressed high HB (>95\%), while $19.2 \%$ of them (11 out of 57 ) showed low HB $(<50 \%)$. The average level of HB in both tests for the 57 colonies was $75 \pm 3.24 \%$ with a range of 19 to $100 \%$.

Due to the loss of two queens in each group, the comparative analysis between the two groups of colonies regarding honey production and infestation levels of $\mathrm{V}$. destructor was done with 16 and 9 colonies of the high and low HB groups, respectively.

No correlation between $\mathrm{HB}$ and the number of combs with brood $(r=0.15, n=57, P=0.47)$ or between $\mathrm{HB}$ and the number of combs covered with bees was found $(r=0.16, n=57, P=0.44)$. Moreover, no significant difference between the two groups of colonies was detected for the number of combs with brood $(t=1.58, d f=23$, $\mathrm{P}=0.52$ ); colonies with high $\mathrm{HB}$ had $9.31 \pm$ 0.14 (mean \pm se) combs with brood, whereas the low HB colonies had $9.29 \pm 0.23$. Likewise, the number of combs covered with bees did not differ $(\mathrm{t}=1.26, \mathrm{df}=23, \mathrm{P}=0.77)$ between the colonies with high $(6.6 \pm .05)$ and low HB 
evaluadas (18 de 57) expresaron un $\mathrm{CH}$ alto (>95\%), mientras que $19.2 \%$ de ellas ( 11 de 57) mostraron un $\mathrm{CH}$ bajo ( $<50 \%)$. El promedio general del $\mathrm{CH}$ en ambas pruebas realizadas a las 57 colonias fue del $75 \pm 3.24 \%$ con un rango de 19 a $100 \%$.

Debido a la pérdida de dos reinas en cada grupo, el análisis comparativo entre ambos grupos de colonias respecto a la producción de miel y los niveles de infestación de $\mathrm{V}$. destructor se realizó con 16 y 9 colonias con $\mathrm{CH}$ alto y bajo, respectivamente.

No se encontró correlación entre el nivel de $\mathrm{CH}$ y el número de panales con cría $(r=0.15, n=$ $57, \mathrm{P}=0.47)$ ni entre el $\mathrm{CH}$ y el número de panales cubiertos con abejas $(r=0.16, n=57$, $P=0.44$ ). Tampoco hubo diferencia significativa entre los dos grupos de colonias con respecto al número de panales con cría ( $\mathrm{t}=1.58$; $\mathrm{gl}=$ 23; $\mathrm{P}=0.52$ ); en las colonias con $\mathrm{CH}$ alto se registraron $9.31 \pm 0.14$ (media \pm ee) y en las de $\mathrm{CH}$ bajo $9.29 \pm 0.23$ panales con cría. Así mismo, el número de panales cubiertos con abejas no varió $(t=1.26 ; g l=23 ; P=0.77)$ entre las colonias con $\mathrm{CH}$ alto $(6.6 \pm 0.05)$ y $\mathrm{CH}$ bajo $(6 \pm 0.09)$, lo cual permite relacionar las diferencias de producción de miel con el $\mathrm{CH}$ y no con la población de las colonias.

Respecto a la producción de miel, la época del año influyó en su producción, siendo el otoño la época de mayor producción $(t=9.51 ; \mathrm{gl}=$ 48; $\mathrm{P}<0.001)$. Sin embargo, sólo durante la primavera las colonias con $\mathrm{CH}$ alto produjeron
( $6 \pm 0.09)$, which allows relating differences in honey production with $\mathrm{HB}$ and not with the bee population of the colonies.

Harvest season influenced honey production, with autumn being the period of greatest production $(t=9.51, d=48, P<0.001)$. However, high $\mathrm{HB}$ colonies produced significantly more honey than colonies with low HB only during the spring season $(t=6.29, d f=23, P=0.001)$. The production values of both groups of colonies for both harvests are shown in Table 1.

The average $\mathrm{V}$. destructor infestation rate of colonies with low HB was $5.3 \pm 0.03 \%$ (range: 0.0 to $17.2 \%$ ), whereas for colonies with high $\mathrm{HB}$ it was $6.7 \pm 0.08$ (range: 0.4 to $31.3 \%$ ), and no significant difference for this variable was found between the two groups of colonies before and during harvests (Table 2).

\section{DISCUSSION}

Although considerable variability was found in HB expression levels among the colonies evaluated, similar percentages between the first and second HB tests were observed, evidence that supports the reliability and discriminatory ability of the $\mathrm{N}_{2}$ freeze-killing test, as reported previously by Espinosa-Montaño et al(43).

The percentage of colonies with high HB found in this study was $31.5 \%$, higher than what has been reported in other countries with EHB. Oldroyd(23) reported that $20 \%$ of colonies tested in Australia had high $\mathrm{HB}$, while this

Cuadro 1. Producción de miel promedio $(\mathrm{kg} \pm$ ee) de colonias de abejas melíferas con comportamiento higiénico alto (HHB) y bajo (LHB) durante las cosechas de otoño y primavera en Zacatecas, México

Table 1. Average honey yield ( $\mathrm{kg} \pm \mathrm{se}$ ) of honey bee colonies with high (HHB) and low (LHB) hygienic behavior during autumn and spring harvests in Zacatecas, Mexico

\begin{tabular}{lccccc}
\hline Harvest season & HHB $(n=16)$ & LHB $(n=9)$ & DF & $t$ & $P$ \\
\hline Autumn & $27.48 \pm 18.9$ & $21.42 \pm 16.9$ & 23 & 1.61 & 0.50 \\
Spring & $21.65 \pm 14.9$ & $13.45 \pm 6.4$ & 23 & 6.95 & 0.01 \\
\hline
\end{tabular}


significativamente más miel que las colonias con $\mathrm{CH}$ bajo ( $\mathrm{t}=6.29, \mathrm{gl}=23, \mathrm{P}=0.001$ ). Los valores de producción en ambos grupos de colonias durante ambas cosechas se muestran en el Cuadro 1.

El grado de infestación promedio de $\mathrm{V}$. destructor en las colonias con bajo $\mathrm{CH}$ fue de $5.3 \pm 0.03 \%$ (rango: 0.0 a $17.2 \%$ ), mientras que el de las colonias con alto $\mathrm{CH}$ fue de 6.7 \pm 0.08 (rango: 0.4 a $31.3 \%$ ), sin encontrarse diferencias significativas para esta variable entre ambos grupos de colonias ni en los meses previos a las cosechas, ni durante éstas (Cuadro 2).

\section{DISCUSIÓN}

No obstante que se encontró una considerable variación en el nivel de expresión del $\mathrm{CH}$ entre las colonias evaluadas, se observaron porcentajes de $\mathrm{CH}$ similares entre la primera y la segunda evaluación, evidencia que respalda la capacidad discriminatoria y de confiabilidad de la prueba de congelamiento con $\mathrm{N}_{2}$, como lo reportaron anteriormente Espinosa-Montaño et al(43).

El porcentaje de colonias con alto $\mathrm{CH}$ encontrado en el presente trabajo fue de $31.5 \%$, superior al registrado en otros países con AE. Oldroyd(23) percentage was only $10 \%$ in another study conducted in the USA(10). Results similar to these (12\%) were found in AHB in Yucatan, Mexico(44). However, it is difficult to know what the representative frequency of colonies with high HB in a population of honey bees is, due to the relatively small sample size $(n=57)$ of this study, and that of the above studies, with which it is compared ( $n<50$ colonies). Future studies should confirm this indicator more accurately.

Although it has been reported that the expression of HB is partly due to various nongenetic factors, including the strength of colony bee populations $(5,45)$, in this study, the expression of HB was not influenced by this factor, since there were no differences in population between colonies with high and low $\mathrm{HB}$, and there was no correlation between $\mathrm{HB}$ levels and the number of combs covered with brood or with adult bees. These results allow a more objective analysis of the association of $\mathrm{HB}$ expression levels with honey production and with infestation levels of $\mathrm{V}$. destructor in honey bee colonies. It could not be speculated that the difference in degree of expression of $\mathrm{HB}$ between the two groups of colonies tested may have been influenced by differences in bee population. Furthermore, all of the colonies were subjected to the same management and to the

Cuadro 2. Número promedio de ácaros de $V$. destructor/100 abejas adultas ( \pm ee) para colonias de abejas melíferas con comportamiento higiénico alto (HHB) y bajo (LHB) 60 días previo a las cosechas de miel de otoño y primavera y durante éstas

Table 2. Average number of $V$. destructor mites/100 adult bees ( $\pm \mathrm{se}$ ) for honey bee colonies with high (HHB) and low (LHB) hygienic behavior $60 \mathrm{~d}$ before and during autumn and spring harvest seasons

\begin{tabular}{lccccc}
\hline Season & $\mathrm{HHB}^{*}(\mathrm{n}=16)$ & $\mathrm{LHB}^{*}(\mathrm{n}=9)$ & $\mathrm{DF}$ & $\mathrm{t}$ & $P$ \\
\hline Preharvest, autumn & $2.69 \pm 0.18$ & $1.90 \pm 0.17$ & 23 & 0.59 & 0.55 \\
Autumn harvest & $6.79 \pm 0.23$ & $7.79 \pm 0.48$ & 23 & 0.51 & 0.61 \\
Preharvest, spring & $6.58 \pm 0.27$ & $7.72 \pm 0.41$ & 23 & 0.86 & 0.39 \\
Spring harvest & $5.27 \pm 0.24$ & $5.75 \pm 0.29$ & 23 & 0.37 & 0.71 \\
\hline
\end{tabular}

*Untransformed values.

$t$ and $P$ values were obtained after square root arcsine transformation of the data. 
reportó que el $20 \%$ de colonias evaluadas en Australia, presentaron un $\mathrm{CH}$ alto, mientras que este porcentaje fue de sólo $10 \%$ en otro estudio realizado en los EUA(10). Resultados similares a estos (12\%) se encontraron en AA de Yucatán, México(44). Sin embargo, es difícil saber cuál es la frecuencia representativa de colonias con alto $\mathrm{CH}$ en una población de abejas, debido al relativamente bajo tamaño de muestra $(n=57)$ de este estudio y de los estudios arriba mencionados, con los que se le puede comparar ( $n<50$ colonias). Futuros trabajos tendrían que confirmar este indicador con mayor precisión.

Aún cuando se ha reportado que la expresión del $\mathrm{CH}$ se debe en parte a diversos factores no genéticos, entre ellos la fortaleza de la población de abejas en las colonias $(5,45)$, en este estudio, la expresión del $\mathrm{CH}$ no estuvo influenciada por este factor, ya que no hubieron diferencias en población entre colonias con alto y bajo $\mathrm{CH}, \mathrm{ni}$ tampoco se encontró correlación entre el nivel de $\mathrm{CH}$ y el número de panales cubiertos con cría o con abejas adultas. Este resultado permite un análisis más objetivo de la asociación del nivel de $\mathrm{CH}$ con la producción de miel y con el nivel de infestación de $\mathrm{V}$. destructor en las colonias de abejas. No se podría especular que la diferencia en grado de expresión del $\mathrm{CH}$ entre los grupos de colonias pudo haber sido influido por diferencias en población. Además, todas las colonias estuvieron sometidas al mismo manejo y a los mismos efectos ambientales de apiario. Por ello, las posibles influencias ambientales en la expresión del $\mathrm{CH}$ de las colonias experimentales fueron limitadas y puede inferirse que las diferencias observadas entre ambos grupos de colonias se debieron más a efectos genotípicos que a ambientales.

El grupo de colonias de alto $\mathrm{CH}$ produjo significativamente más miel ( $23 \%$ más) que el grupo de colonias con $\mathrm{CH}$ bajo durante la cosecha de primavera. Estos resultados coinciden con los reportados en AE por Spivak y Reuter(24), quienes encontraron que las colonias seleccionadas para alto $\mathrm{CH}$, con reinas apareadas naturalmente, produjeron $26 \%$ más same apiary environmental effects. Thus, the possible environmental influences on $\mathrm{HB}$ expression of the experimental colonies were limited, and it can be inferred that the observed differences between the two groups of colonies were due more to genotypic than to environmental effects.

The group of high HB colonies produced significantly more honey $(23 \%)$ than the group of colonies with low HB during the spring harvest. These results agree with those reported in EHB by Spivak and Reuter(24), who found that the colonies selected for high $\mathrm{HB}$, with naturally mated queens, produced $26 \%$ more honey than the commercial colonies not selected for this behavior. In another study in which instrumentally inseminated EHB, selected for high and low HB were used, it was also found that the hygienic colonies produced significantly more honey than the non-hygienic ones(35). Moreover, it is well established that $\mathrm{HB}$ reduces the manifestation of brood diseases $(26-32,35,46)$. Therefore, the expression of HB may indirectly contribute to obtain greater honey yields, by decreasing disease frequency in bee colonies.

It has been reported that non-hygienic bees can be induced to increase their expression of $\mathrm{HB}$ under strong enough environmental stimuli(22). For example, when there is abundant nectar and pollen in the field, the expression of $\mathrm{HB}$ also increases, because the need for space to store these products is created in the colony and that also stimulates the queen to lay more eggs in cells that should be clean $(8,9,11,24)$. This agrees with the results of this study, since during the autumn (season with more intense nectar flow than spring) $16.4 \%$ more honey was produced than during the spring, but no differences were found between the two groups of colonies for this variable. Conversely, in the spring, the high HB colonies produced significantly more honey $(23 \%)$ than the low $\mathrm{HB}$ colonies. These results suggest that high HB may have a greater influence on honey production under conditions where the nectar flow is not very intense. 
miel que las colonias comerciales no seleccionadas para este comportamiento. En otro estudio en el que se usaron $A E$ seleccionadas para alto y bajo $\mathrm{CH}$, mantenidas mediante inseminación instrumental, también se encontró que las colonias higiénicas produjeron significativamente más miel que las no higiénicas(35). Además de lo anterior, está bien establecido que el $\mathrm{CH}$ reduce la manifestación de enfermedades de la cría(26$32,35,46)$. Por ello, la expresión del $\mathrm{CH}$ puede contribuir indirectamente a la obtención de una mayor producción de miel, al reducir la frecuencia de enfermedades en las colonias.

Se ha reportado que las abejas poco higiénicas pueden ser inducidas a expresar el $\mathrm{CH}$ en mayor medida ante un estímulo medioambiental suficientemente fuerte (22). Por ejemplo, cuando hay abundancia de néctar y polen en el campo, se incrementa la expresión del $\mathrm{CH}$ de las abejas, debido a que se crea la necesidad de espacio para almacenar estos productos en la colonia y porque ello también estimula a la reina a poner en celdillas que deben estar limpias $(8,9,11,24)$. Lo anterior concuerda con los resultados del presente estudio, ya que durante el otoño (época con flujo más intenso de néctar que en la primavera) se produjo $16.4 \%$ más miel que en la primavera, pero no se encontraron diferencias entre los dos grupos de colonias. Contrario a esto, en la primavera, las colonias con $\mathrm{CH}$ alto produjeron significativamente más miel $(23 \%)$ que las colonias con $\mathrm{CH}$ bajo. Lo anterior sugiere que el $\mathrm{CH}$ alto pudiera tener un mayor efecto sobre la producción de miel bajo condiciones donde el flujo de néctar no es muy intenso.

En el presente estudio, no se detectaron diferencias para los niveles de infestación de V. destructor entre las colonias con $\mathrm{CH}$ alto y bajo. Este resultado abona a la inconsistencia de resultados reportados en la literatura respecto a la influencia del $\mathrm{CH}$ sobre el grado de varroosis de las colonias de abejas. A la fecha, resulta difícil afirmar que el $\mathrm{CH}$ confiere o no, resistencia a las colonias de abejas contra V. destructor de
Under the conditions of this study, no differences in V. destructor infestation levels were detected between colonies with high and low HB. This result adds to the inconsistency of results reported in the literature regarding the influence of HB on the degree of varroosis of honeybee colonies. At the present time, it is difficult to say whether or not HB confers resistance to honey bee colonies against $\mathrm{V}$. destructor in all cases because as reported in the literature, results of different experiments vary considerably. Even with stock selected during several generations for high $\mathrm{HB}$ using instrumental insemination, it has been found that there is variability among colonies for $\mathrm{V}$. destructor resistance, which has been attributed to different environmental or methodological conditions in each study $(29,35)$.

Some studies conducted with EHB have concluded that $\mathrm{HB}$ is not one of the main mechanisms of resistance against Varroa. For example, in an experiment conducted in the USA where colonies were assessed for $\mathrm{HB}$, capped cell period, suppression of $\mathrm{V}$. destructor reproduction and grooming behavior of the bees, it was found that the only mechanism of resistance associated with the mite's population growth was the suppression of Varroa female reproduction(47); it has also been mentioned that $\mathrm{HB}$ is effective against the mite, only when a colony expresses this property at a very high level(24,35,48).

Varroa has caused large losses of colonies in temperate and cold climates and has eliminated feral bee populations(48). However, this does not appear to be a serious problem in parts of the world where AHB are present and where low levels of mite infestation and various bee defense mechanisms have been described. Because of this, and based on the results of this study, it can be speculated about the possibility that tolerance mechanisms other than HB are operating against Varroa in the semiarid high plateau of Mexico.

Factors contributing to the resistance of bees against Varroa, may not be the same for all 
acuerdo a lo reportado en la literatura, ya que los resultados de diferentes experimentos varían considerablemente. Aún en trabajos realizados con abejas seleccionadas por varias generaciones para mayor expresión del $\mathrm{CH}$ y reproducidas por medio de inseminación instrumental, se ha encontrado variación en la resistencia a $\mathrm{V}$. destructor entre colonias con $\mathrm{CH}$ alto, lo cual ha sido atribuido a diferentes condiciones ambientales o metodológicas presentes en cada estudio $(29,35)$.

Existen estudios realizados con $\mathrm{AE}$ en los cuales se concluye que el $\mathrm{CH}$ no es uno de los principales mecanismos de resistencia de las abejas contra Varroa. Por ejemplo, en un experimento realizado en los EUA donde se evaluó el $\mathrm{CH}$, el periodo de operculación de las celdas, la supresión de la reproducción de V. destructor y el comportamiento de acicalamiento de las abejas, se encontró que el único mecanismo de resistencia relacionado con el crecimiento poblacional del ácaro fue la supresión de la reproducción de las hembras de Varroa(47); también se ha mencionado que el $\mathrm{CH}$ es efectivo sólo cuando una colonia expresa esta característica a un nivel muy alto $(24,35,48)$.

Varroa ha ocasionado grandes pérdidas de colonias en países de clima templado o frío y ha eliminado a la población de colonias silvestres(48). Sin embargo, esto no parece ser un serio problema en lugares del mundo donde existen $\mathrm{AA}$, en donde se reportan bajos niveles de infestación del ácaro y diferentes mecanismos de defensa de las abejas han sido descritos. Por lo anterior y basándonos en los resultados del presente estudio, se puede especular sobre la posibilidad de que otros mecanismos de tolerancia diferentes al $\mathrm{CH}$ estén operando frente a Varroa en las abejas del altiplano semiárido de México.

Los factores que contribuyen a la resistencia de las abejas a Varroa, pueden no ser los mismos en todas las poblaciones de abejas. La baja fertilidad del ácaro se ha considerado como el bee populations. Low mite fertility has been considered as the main mechanism of tolerance to varroosis in the USA(47); however, in other countries, low brood attractiveness to the mite, grooming behavior and HB show association with low infestation levels of $\mathrm{V}$. destructor $(30,49)$. Therefore, some traits that have a strong influence in conferring tolerance against the mite in bee populations of certain regions of the world may not have it in others.

The present study shows the first evidence suggesting a possible influence of high HB on honey production in AHB colonies. If this result is confirmed, the selection of colonies with high HB could be an alternative way to contribute to increase honey yields of honeybee colonies, particularly where blooming plants do not generate intense nectar flows. The HB of worker bees is inherited mainly from the mother, rather than from the father, probably through extranuclear inheritance(15), therefore, it would be possible to conduct selective breeding programs by using queen sources without selecting the paternal side, which would be easy to adopt by most queen breeders in Mexico.

\section{CONCLUSIONS AND IMPLICATIONS}

Based on the results obtained and under the conditions of this study, it is concluded that $31.5 \%$ of the colonies analyzed expressed high HB (>95\%) and this trait was not influenced by the strength of the colonies. Additionally, the levels of $\mathrm{V}$. destructor infestation on adult bees in colonies with high and low HB did not vary significantly. During spring, the high HB colonies produced significantly more honey than the low HB colonies. These results do not support the conclusion that the HB of bees has a significant influence on their degree of infestation by $V$. destructor, although it may have an effect on honey production under conditions of limited nectar flow. 
principal mecanismo de tolerancia a la varroosis en los EUA(47), sin embargo, en otros países, la baja atracción de la cría, el comportamiento de acicalamiento y el $\mathrm{CH}$ muestran asociación con niveles bajos de infestación por $\mathrm{V}$. destructor(30,49), por lo que algunas características que tienen una fuerte influencia en conferir tolerancia al ácaro en ciertas poblaciones de abejas y regiones del mundo, pueden no tenerla en otras.

El presente estudio muestra la primera evidencia que sugiere una posible influencia del $\mathrm{CH}$ alto en la producción de miel en colonias de AA. De confirmarse este resultado, la selección de colonias con $\mathrm{CH}$ alto pudiera ser una alternativa para contribuir a la obtención de colonias con mayor producción de miel, particularmente donde las floraciones no generan flujos intensos de néctar. $\mathrm{El} \mathrm{CH}$ se hereda principalmente a través de la madre, probablemente por herencia extra-nuclear(15), por ello, sería posible llevar a cabo programas de selección vía materna sin necesidad de seleccionar el lado paterno, lo cual sería fácil de adoptar por la mayoría de los criadores de reinas en México.

\section{CONCLUSIONES E IMPLICACIONES}

Con base en los resultados obtenidos se concluye que el $31.5 \%$ de las colonias analizadas expresaron $\mathrm{CH}$ alto (> $95 \%$ ), y esta característica no estuvo influenciada por la fortaleza de las colonias. Además, los niveles de infestación por $\mathrm{V}$. destructor en abejas adultas de colonias con $\mathrm{CH}$ alto y bajo no variaron significativamente. Durante la primavera, las colonias con $\mathrm{CH}$ alto produjeron significativamente más miel que las colonias con $\mathrm{CH}$ bajo. Estos resultados no permiten afirmar que el $\mathrm{CH}$ tiene una influencia significativa sobre su grado de infestación por V. destructor, aunque es posible que tenga efecto sobre la producción de miel bajo condiciones de flujo limitado de néctar.

\section{ACKNOWLEDGEMENTS}

We thank the Consejo Nacional de Ciencia y Tecnologia (CONACYT) and the government of the State of Zacatecas, for funding granted (project FOMIX: ZAC -2003- C01- 0058).

End of english version

\section{AGRADECIMIENTOS}

Se agradece al Concejo Nacional de Ciencia y Tecnología (CONACyT) y al Gobierno estatal de Zacatecas, por el financiamiento otorgado (proyecto: FOMIX:ZAC-2003-C01- 0058).

\section{LITERATURA CITADA}

1. Rothenbuhler WC. Behavior genetics of nest cleaning in honey bees. I. Responses of four inbred lines to disease killed brood. Anim Behav 1964; 12:578-583.

2. Boecking $\mathrm{O}$, Drescher $\mathrm{W}$. Apis mellifera removes Varroa jacobsoni and Tropilaelaps clareae from sealed brood cells in the tropics. Am Bee J 1992:132(11):732-734.

3. Arathi HS, Ho G, Spivak M. Inefficient task partitioning among nonhygienic honeybees, Apis mellifera L., and implications for disease transmission. Anim Behav 2006; 72:431-438.

4. Harbo J R, Harris JW. Responses to Varroa by honey bees with different levels of Varroa Sensitive Hygiene. J Apic Res Bee World 2009;48(3): 156-161.

5. Spivak M, Gilliam M. Facultative expression of hygienic behaviour of honey bees in relation to disease resistance. J Apic Res 1993:32(3/4):147-157.

6. Arathi HS, Burns I, Spivak M. Ethology of hygienic behavior in the bee Apis mellifera L. (Hymenoptera: Apidae) behavioural repertoire of hygienic bees. Ethology 2000; 106: 365-379.

7. Arathi HS, Spivak M. Influence of colony genotypic composition on the performance of behaviour in the honeybee, Apis mellifera L. Anim Behav 2001;62:57-66.

8. Thompson VC. Behaviour genetics of nest cleaning in honeybees. III. Effect of age of bees of a resistant line on their response to disease-killed brood. J Apic Res 1964;3(1):25-30.

9. Palmquist MJ, Rothenbuhler W. Behaviour genetics of nest cleaning in honeybees. VI. Interactions of age and genotype of bees, and nectar flow. J Apic Res 1971;101:11-21. 
10. Spivak M, Reuter GS. Honey bee hygienic behavior. Am Bee J 1998; 138(4):238-286.

11. Janmaat FA, Winston LM. Removal of Varroa jacobsoni infested brood in honey bee colonies with differing pollen stores. Apidologie 2000;31:377-385.

12. Rothenbuhler WC. Behavior genetics of nest cleaning in honey bees. IV. Responses of F1 and backcross generations to disease - killed brood. Anim Behav 1964;4:11-123.

13. Moritz RFA. A Reevaluation of the two locus model for hygienic behavior in honeybees (Apis mellifera L.). J Hered 1988; 79:257-262.

14. Lapidge LK, Oldroyd PB, Spivak M. Seven suggestive quantitative trail loci influence hygienic behavior of honey bees. Naturwissenschaften 2002;89:565-568.

15. Unger P, Guzmán-Novoa E. Maternal Effects on the Hygienic Behavior of Russian x Ontario Hybrid Honeybees (Apis mellifera L.). J Hered 2010;101(1):91-96.

16. Oxley PR, Spivak M, Oldroyd BP. Six quantitative trait loci influence task thresholds for hygienic behaviour in honeybees (Apis mellifera). Mol Ecol 2010;19(7):1452-1461.

17. Harbo J R, Harris JW. Heritability in Honey Bees (Hymenoptera: Apidae) of Characteristics Associated with Resistence to Varroa jacobsoni (Mesostigmata:Varroidae). J Econ Ent 1999; 92(2):261-265.

18. Boecking $\mathrm{O}$, Spivak M. Behavioral defenses of honey bees against Varroa jacobsoni Oud. Apidologie 1999; 30:141-158.

19. Boecking O, Bienefeld K, Drescher W. Heritability of the Varroa-specific hygienic behaviour in honey bees (Hymenoptera Apidae). J Anim Breed Genetic 2000; 117:417424.

20. Stanimirovic Z, Stevanovic J, Mirilovic M, Stojic V. Heritability of hygienic behaviour in grey honey bees (Apis mellifera carnica) Acta Vet (Beograd) 2008;58(5-6):593-601.

21. Newton D, Ostasiewski N. A simplified bioassay for behavioral resistance to American foulbrood in honey bees (Apis mellifera L.). Am Bee J 1986; 126:278-281.

22. Spivak M, Downey DL. Field assays for hygienic behavior in honey bees (Hymenoptera: Apidae). J Econ Entomol 1998; 91: 1:64-70.

23. Oldroyd BP. Evaluation of Australian commercial honey bees for hygienic behaviour, a critical character for tolerance to chalkbrood. Aust J Exp Agric 1996;36:625-629.

24. Spivak M, Reuter GS. Performance of hygienic honey bee colonies in a commercial apiary. Apidologie 1998;29:291302.

25. Palacio MA, Figini EE, Ruffinengo SR, Rodriguez EM, Hoyo $\mathrm{ML}$, Bedascarrasburne EL. Changes in population of Apis mellifera L. selected for the hygienic behavior and its relation to brood disease tolerance. Apidologie 2000;31:471-478.

26. Gilliam M, Taber S, Richardson VG. Hygienic behavior of honey bees in relation to chalkbrood disease. Apidologie 1983; 14(1): 29-39.

27. Milne CPJ r. Honey bee (Hymenoptera:Apidae) hygienic behavior and resistance to chalkbrood. Ann Entomol Soc Am 1983; 76:384-387.

28. Spivak M, Gilliam M. Hygienic behaviour of honey bees and its application for control of brood diseases and Varroa. Part II. Studies on hygienic behaviour since the Rothenbuhler era. Bee World 1998;79:4:169-186.
29. Spivak M. Honey bee hygienic behavior and defense against Varroa jacobsoni. Apidologie 1996;27:245-260.

30. Arechavaleta-Velasco ME, Guzmán-Novoa E. Relative effect of four characteristics that restrain the population growth of the mite Varroa destructor in honey bee (Apis mellifera) colonies. Apidologie 2001;32:157-174.

31. Spivak M, Reuter GS. Resistance to American foulbrood disease by honey bee colonies Apis mellifera bred for hygienic behavior. Apidologie 2001;32:555-565.

32. Ibrahim A, Reuter GS, Spivak M. Field trial of honey bee colonies bred for mechanisms of resistance against Varroa destructor. Apidologie 2007;38:67-76.

33. Moretto G, Goncalves SL, De Jong D. Africanized bees are more efficient at removing Varroa jacobsoni- Preliminary data. Am Bee J 1991; 131:434.

34. Vandame R, Colin M, Colina OG. Africanized honeybees tolerance to Varroa in México: mite infertility is not main tolerance factor. Apiacta 1999;34:12-20.

35. Spivak M, Reuter GS. Varroa destructor infestation in untreated honey bee (Hymenoptera:Apidae) colonies selected for hygienic behavior. J Econ Entomol 2001;94(2):326-331.

36. INEGI. Instituto Nacional de Estadística Geografía e Informática. Municipios de Zacatecas. 2001;234-235.

37. Jay CS. Colour changes in honeybee pupae. Bee World 1962; 43(4): 115-117.

38. Message D, Goncalves LS. Efeito das condicones climaticas a da colonia no compotamento higienico em abelhas Apis mellifera (africanizadas). Anais do 5o Congresso Brasileiro de Apicultura (Minas Gerais) 1980:55.

39. Sylvester HA, Rinderer TE. Fast Africanized Bee Identification System (FABIS) Manual. Am Bee J 1987;127(7):511-516.

40. Guzmán-Novoa E, Page R. Selective breeding of honey bees (Hymenoptera: Apidae) in africanized areas. J Econ Entomol 1999; 92:521-525.

41. De J ong D, Roma DA, Goncalves LS. A comparative analysis of shaking solutions for the detection of Varroa jacobsoni on adult honeybees. Apidologie 1982; 13:297-306.

42. SAS. Statistical Analysis System. 2002. version 9.0, Cary, NC.

43. Espinosa-Montaño LG, Guzmán-Novoa E, Sánchez-Albarrán A, Montaldo HH, Correa-Benítez A. Estudio comparativo de tres pruebas para evaluar el comportamiento higiénico en colonias de abejas (Apis mellifera L.) Vet Méx 2008; 39(1):3954.

44. Medina-Flores CA, Medina ML. Frecuencia de colonias altamente higienistas en abejas africanizadas (Apis mellifera) de Yucatán. Seminario Americano de Apicultura; Aguascalientes, México.: Unión Nacional de Apicultores. 2003:69-72.

45. Najafgholian J, Thahmasbi G, Pakdel A, Nehzati G. Effect of population size on the expression of hygienic behavior in the iranian honey bee (Apis mellifera meda). Asiatic J Biotech Res 2011;2(4):364-373.

46. Spivak M, Gilliam M. Hygienic behaviour of honey bees and its application for control of brood diseases and Varroa. Part I. Hygienic and resistance to American foulbrood. Bee World 1998; 79(3): 124-134.

47. Harbo J R, Hoopingarner RA. Honey bees (Hymenoptera: Apidae) in the United States that express resistance to 
Carlos Aurelio Medina-Flores, et al. / Rev Mex Cienc Pecu 2014;5(2):157-170

Varroa jacobsoni (Mesostigmata:Varroidae). J Econ Entomol 1997; 90(4): 893-898.

48. Mondragón L, Spivak M, Vandame R. A multifactorial study of the resistance of honeybees Apis mellifera to the mite Varroa destructor over one year in Mexico. Apidologie 2005; 36:345-358.
49. Guzman-Novoa E, Emsen B, Unger P, Espinosa-Montaño LG, Petukhova T. Genotypic variability and relationships between mite infestation levels, mite damage, grooming intensity, and removal of Varroa destructor mites in selected strains of worker honey bees (Apis mellifera L.). J Invert Pathol 2012; 110:314-320. 